\title{
The Astronomical Orientation of Ancient Greek Theatres in Relation to the Topography and the Greek Mythology
}

\author{
George Pantazis \\ Laboratory of General Geodesy, School of Rural and Surveying Engineering, National Technical University of Athens, Greece
}

Copyright@2017 by authors, all rights reserved. Authors agree that this article remains permanently open access under the terms of the Creative Commons Attribution License 4.0 International License

\begin{abstract}
The study of the astronomical orientation of monuments in Greece has been strengthened over the last decade by the development and application of contemporary methods of measurement and analysis. The study has highlighted important findings related to monuments from the Antiquity up to the modern era. This study includes monuments of the classical antiquity, early Christian basilicas, Byzantine temples and mosques. However, an equally important Monument category is the ancient theatres. These monuments due to both their size and usefulness became the subject of study in this paper. This paper presents the results of a systematic research concerning the determination of the astronomical orientation of six ancient theatres in Greece. At the same time, the interpretation of their orientation and their possible relation to the mythology, the position and movement of constellations and the topography of their site is also studied. The geometric data produced with modern accurate methods of measurement and analysis certainly contributes to a more thorough study and interpretation of the placement and orientation of such large ancient constructions. This systematic research is carried out for six of the most important theatres in Greece. These are the ancient theatres of Dionysus, Delphi, Epidaurus, Ancient Epidaurus, Argos and Sicyon.
\end{abstract}

Keywords Ancient Theaters, Astronomical Orientation, Geometric Documentation, Astrogeodetic Method, Dionysus, Delphi, Epidaurus, Ancient Epidaurus Argos, Sicyon

\section{Introduction}

It is known that Archaeoastronomy is the science, which studies the interpretation of the orientation of the monuments. It is considered to be the meeting point between astronomy and archaeology. In Greece, systematic research took place dating back to the last decades of the 19th century (1885) thanks to the works of Heinrich Nissen [1], Norman Lockyer [2] and Francis Penrose [3, 4], who studied the orientation of Greek temples in the continental and insular Greece. Nissen
(1907) and Penrose (1897) identified the constellations to which some of the ancient Greek temples were oriented, and claimed that they could also specify the exact date of construction for each of them. This investigation has been strengthened by up-to-date methods of measurement and analysis over the last 15 years for at least 100 monuments in Greece [5-9].

The investigation of the astronomical orientation of ancient monuments has revealed significant findings that concern the monuments from the moment of their construction, their placement and the reason of their existence. The study of the astronomical orientation of ancient monuments requires their geometrical documentation. During this process, with the use of geometrical methods, the shape, size and position of each monument are assigned, which is a fundamental element to the progress of the study. However, this investigation does not yet include the ancient theatres. The correlation of ancient theatres' astronomical orientation with the movement of celestial bodies or religious celebrations requires the systematic recording and study of historical and mythological data. Also the creation of their astronomical-oriented plans is essential.

In the sections below, the techniques and methods which are used will be analyzed, as well as the results arising from the aforementioned procedures for a group of six ancient theatres in Greece will be presented.

\section{The Ancient Theatres}

Ancient theatres are an outdoor amphitheatrical construction [10] of a semi-circular ground plan around a circular square (figure 1). In ancient times, performances were held only in specific periods and mainly had a devotional purpose to the god to whom each theatre was dedicated. The earliest form of theatre appears to be the dithyramb and group round dances. The first performance, where an actor is interacted with the "Chorus", took place during the Great Dionysia in 534 BC. Along with the evolution of the dithyramb into ancient drama or comedy, the 
form of the ancient theatre evolves as it is presented in figure 1. In its original form, around the 6th century BC, the ancient theatre consisted of a circular space, the orchestra, which was placed on a flattened space at the foot of a hill and the slope which was used as the place where the audience sat. In the 5th century BC, the "koilon" of the theatre is created, which was originally coated with wooden benches, the "ikriomata". Eventually, its stone form will prevail. The last piece embedded in the ancient theatre is the scene, "skene" [11].

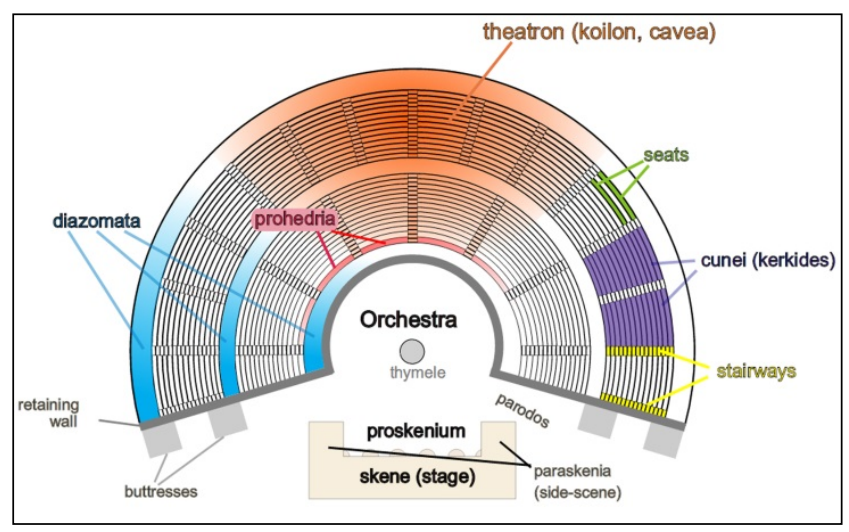

Figure 1. Basic elements of an ancient theatre structure

This study consists of the ancient theatres of Dionysus, Epidaurus, Ancient Epidaurus, Argos, Delphi and Sicyon.

The ancient theatre of Dionysus is dated around the 6th century $\mathrm{BC}$, and is located at the southern slope of the Acropolis in the prefecture of Attica. It is considered to be the first ancient theatre of Greece and it appears that most of the extant tragedies were written to be performed there. The theatre is dedicated to the god Dionysus and performances were held, during the Great (also called City) and Rural Dionysia celebrations.

The ancient theatre of Epidaurus is located at the eastern side of Mount Kynortio in the prefecture of Argolis and it is dated back to the end of the classical period, circa 340-330 BC [12]. This is the finest preserved theatre and it stands out for its amazing acoustics. It was built in honor of the god Asclepius while the music and singing contests of Asclepieia took place there.

The ancient theatre of the village of Ancient Epidaurus is located at its eastern side, in the prefecture of Argolis. Its construction seems to have begun in the 4th century BC, developing up until the Hellenistic period and it is dedicated also to the god Asclepius.

The ancient theatre of Argos is constructed at the prefecture of Argolis, in the southeast side of the castle. It is considered to be one of the biggest ancient theatres since it has a capacity of 20.000 spectators. Dated around the 3rd century BC, the theatre hosted the Nemean drama contests, related to the worship of the god Zeus.

The ancient theatre of Sicyon is placed at the hill of the modern village Vasiliko, located $4 \mathrm{~km}$ southeast of Kiato, in the prefecture of Corinth. It is dated circa 330-251 BC, in the Hellenistic period. The theatre is dedicated to the god Apollo and celebration events in his honor were also hosted there.

Finally, the ancient theatre of Delphi is located in the archaeological site of Delphi at the foot of the mount Parnassus, in Phocis prefecture. Vocal and instrumental music competitions were held in the theatre, as part of the Pythia games as well as other rituals. The theatre was dedicated to Apollo Musagete. Moreover, the Sotiria games in honor of Zeus the Saviour and Apollo were also hosted in this theatre.

\section{Documentation Method}

The purpose of the geometrical documentation of the ancient theatres is to create plans in an arbitrary local reference system, oriented in relation to the astronomical north. By using these plans the main axis of each theatre as well as its astronomical azimuth, which are necessary for further investigation are determined. Also the possible correlation with stars and star formations or special celestial bodies and constellations are examined.

For all the theatres, the necessary measurements were carried out for the transformation of the already existing plans to the required reference system. The reference system, as mentioned above, is a local arbitrary system, with arbitrary initial coordinates (e.g. 100, 100, H) and the direction of the Y-axis towards the astronomical north. Along with the terrestrial measurements carried out at each theatre, measurements with GNSS (Global Navigation Satellite System) receivers also took place, in order to determine the geodetic coordinates $(\varphi)$ and $(\lambda)$ in WGS84 (World Geodetic System), which is necessary for the investigation of the astronomical orientation. The measurements are related to either older benchmarks, which appear in the existing plans or within the field of measurements, or characteristic points, which could be identified with the ones that appear in the plans. By using the AutoCAD software the transformation of the existing plans to the oriented system was achieved. Practically, it is about shifting the plan, changing the scale, and turning the axes. For the transformation process, not all the measured points were included as a minimum of three points only are indispensable. An average adaptation error resulted from the points that were included in the transformation, which is approximately $\pm 5 \mathrm{~cm}$ and it is considered satisfactory.

The instrumentation which was used for the survey was a Leica TCR 1201 total station, which is able to measure distances with and without the use of a reflector and also two Trimble 5800 GNSS receivers were used for the initial coordinate's calculation.

\section{Astronomical Orientation of Theatres}

In order to achieve the astronomical orientation of the theatres, sightings to the Pole star ( $\alpha$ Ursa minoris or Polaris) were carried out, by using the total station. Using the method 
of the hour angle [5], the astronomical azimuth of the direction between two survey benchmarks, in each theatre is calculated. As a result, the astronomical oriented plans were created.

Having completed the measurements and the necessary transformations, the direction, by which the orientation of each theatre will be studied, was chosen. This direction is the main axis of each theatre. This axis comes through the appropriate points of either the central tier of the theatre or its central scale (figure 2). Using the method of the least squares, the best fitting line to the appropriate points was calculated. The next step of the process is the determination of the astronomical azimuth of the main axis.

As astronomical azimuth of the main axis of an ancient theatre is defined the clockwise angle which is formed from the direction of the astronomical north to the direction which is defined by the main axis of the theatre, from the hollow (koilon) to the orchestra (figure 2). Namely the looking direction of the audience sited at the central tier of the theatre. Table 1 presents the astronomical azimuths of the main axes of the six theatres with the corresponding accuracies. Also picture 3 illustrates the astronomical oriented plans of the theatres.

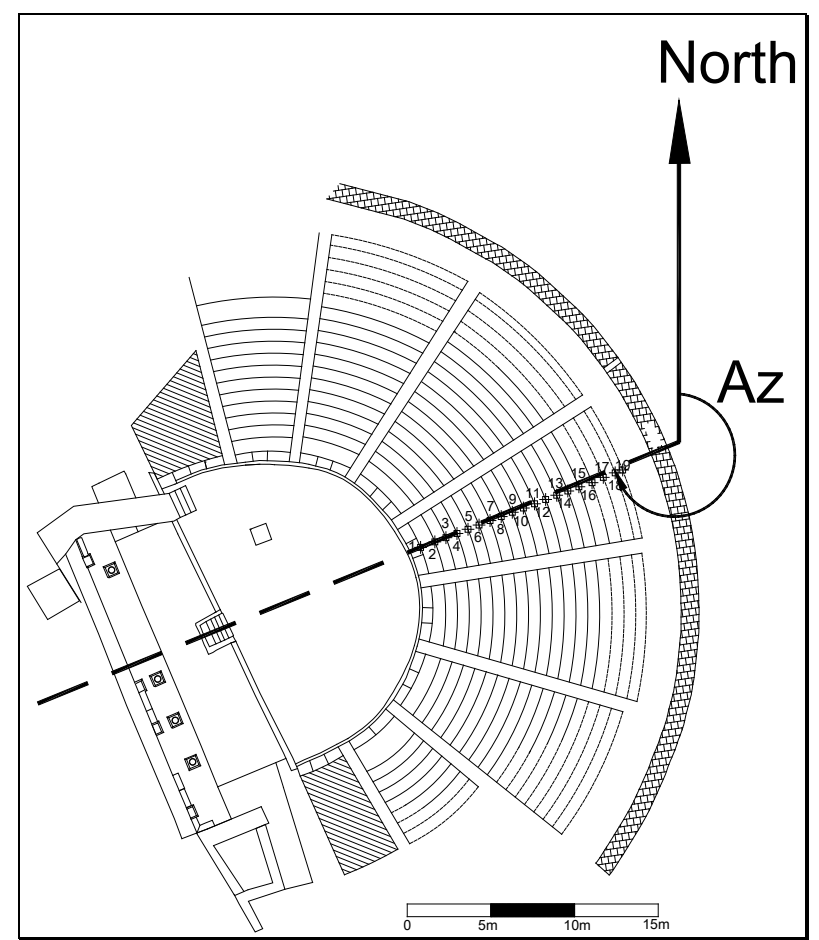

Figure 2. Definitions of the main axis and the astronomical azimuth of main axis of a theatre

Table 1. Astronomical azimuths of main axes

\begin{tabular}{|c|c|c|c|c|}
\hline Theatre & \multicolumn{3}{|c|}{ Astronomical Azimuth } & Azimuth’s error \\
\hline Dionysus & $161^{\circ}$ & $32^{\prime}$ & $27^{\prime \prime}$ & $\pm 1^{\prime} 37^{\prime \prime}$ \\
\hline Epidaurus & $332^{\circ}$ & $03^{\prime}$ & $23^{\prime \prime}$ & $\pm 1^{\prime \prime}$ \\
\hline Ancient Epidaurus & $248^{\circ}$ & $44^{\prime}$ & $31^{\prime \prime}$ & $\pm 5^{\prime} 24^{\prime \prime}$ \\
\hline Argos & $106^{\circ}$ & $15^{\prime}$ & $46^{\prime \prime}$ & $\pm 2^{\prime} 10^{\prime \prime}$ \\
\hline Sicyon & $51^{\circ}$ & $39^{\prime}$ & $36^{\prime \prime}$ & $\pm 3^{\prime} 47^{\prime \prime}$ \\
\hline Delphi & $141^{\circ}$ & $41^{\prime}$ & $29 "$ & $\pm 13^{\prime \prime}$ \\
\hline
\end{tabular}




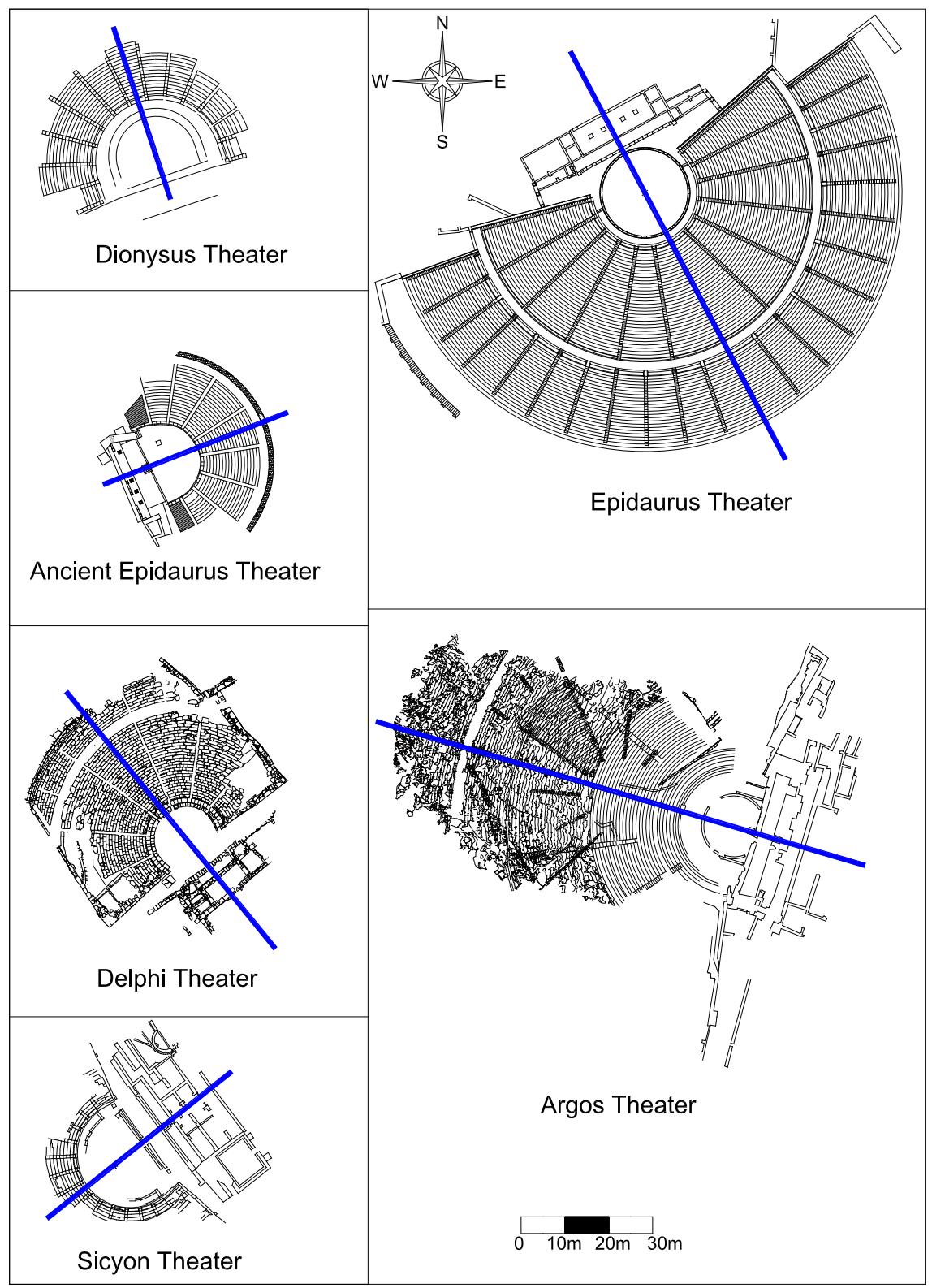

Figure 3. Relevant position of the main axes of theatres

\section{The Relation to the Constellations and the Greek Mythology}

Firstly, it is necessary to define the period during which the performances were held and transform them to their modern equivalent. The specific dates of the performances are presented on Table 2. The outcome of this research also showed an average time period, aided by our knowledge on the chronology of theatres. What was also researched was the relation that the astronomical azimuths of the main axes of ancient theatres might have had to certain stars or star formations as well as to certain planets for each one of these dates during the average time period that each theatre is known to have been built. Investigating the orientation in relation to the Sun the following are came out:

For the theater of Dionysus, Argos and Delphi the corresponding Azimuths (161 $32^{\circ} 27^{\prime \prime}, 106^{\circ} 15^{\prime} 46^{\prime \prime}$ and $\left.141^{\circ} 41^{\prime} 29^{\prime \prime}\right)$ are in accordance with the commence time of the performances $(12 \mathrm{~h}, 8 \mathrm{~h}$ and $11 \mathrm{~h})$ as it is well known that they were took place during the daylight. On the contrary at the theatre of Ancient Epidaurus the sun's path coincides its axis $\left(248^{\circ} 44^{\prime} 31^{\prime \prime}\right)$, during the sunset at the end of the performances. 
Table 2. Dates of celebration of ancient theatres

\begin{tabular}{|c|c|c|c|c|c|}
\hline \multirow{2}{*}{ Theatre } & \multirow{2}{*}{ God } & \multirow{2}{*}{ Constellation } & \multirow{2}{*}{ Celebration } & \multicolumn{2}{|c|}{ Date } \\
\hline & & & & Contemporary & Ancient (month) \\
\hline \multirow{3}{*}{ Dionysus } & \multirow{3}{*}{ Dionysus } & \multirow{3}{*}{$\begin{array}{l}\text { Hyades } \\
\text { Taurus }\end{array}$} & The Great (City) Dionysia & March 3-8 ${ }^{\text {th }}$ & Elaphebolion $8-13^{\text {th }}$ \\
\hline & & & The Rural Dionysia & November $30^{\text {th }}$ to December $3^{\text {rd }}$ & Poseideon $8-11^{\text {th }}$ \\
\hline & & & The Lenaia & End of December-January & Gamelion \\
\hline Epidaurus & Asclepius & Sagittarius & \multirow[b]{2}{*}{ The Asclepieia } & \multirow{2}{*}{$\begin{array}{l}\text { End of March-April or } \\
\text { end of June-July }\end{array}$} & \multirow[b]{2}{*}{ Munychion or Hekatombaion } \\
\hline $\begin{array}{c}\text { Ancient } \\
\text { Epidaurus }\end{array}$ & Asclepius & Serpens & & & \\
\hline Argos & Zeus & Aquila & The Nemean & End of June-July & Hekatombaion \\
\hline Sicyon & Apollo & Lyra & The Apollonian & May $1^{\text {st }}$ & Thargelion $7^{\text {th }}$ \\
\hline \multirow{7}{*}{ Delphi } & \multirow{7}{*}{ Apollo } & \multirow{7}{*}{$\begin{array}{c}\text { Lyra } \\
\text { Vega } \\
\text { (a Lyra’s) }\end{array}$} & Apollo’s birthday & February $22^{\text {nd }}$ & Vysion 7 \\
\hline & & & The Theofania & March $21^{\text {st }}$ & Spring Equinox \\
\hline & & & The Pythia & May $21^{\text {st }}$ & Heraclion 6 \\
\hline & & & Summer solstice & June $21^{\text {st }}$ & Summer Solstice \\
\hline & & & The Pythia & August $22^{\text {nd }}$ & Voukation 7 \\
\hline & & & The Septeria & September $22^{\text {nd }}$ & Autumnal Equinox \\
\hline & & & Winter solstice & December $21^{\text {st }}$ & Winter solstice \\
\hline
\end{tabular}

The research continued with the study of full star constellations. From the latter, it appears that the orientation of each ancient theatre is towards to a constellation, which is relevant to the mythology of the god to which the theatre is dedicated. For this research, due to the fact that the size of constellations differs in range, an average axis of the constellations and the astronomical azimuth of this axis is used, during different time periods.

The main axis of the theatre of Dionysus, during the celebration period of the Great Dionysia and Lenaia, meets the Hyades constellation, which is part of Taurus constellation, at a vertical angle of $60^{\circ}$ at 21.00 o'clock. [13]. This happens during the period starting from December 1st until January 25th. The period that the Rural Dionysia are celebrated there is a total view from the site to the Hyades constellation which consists of 34 stars, adjacent to Taurus. According to mythology Hyades were the daughters of Plioni and Atlas. When Dionysus was born his father Zeus, asked them to breed his son. Also Hyades are identified as the nymphs of Dodoni, who are the followings of Dionysus, as Ambrosia, who was metamorphosed in to vine, and Koronida.

At the theatre of Epidaurus, during the celebration period of Asclepieia (June $22^{\text {nd }}$ to July $21^{\text {st }}$ ) the main axis of the theatre meets the Sagittarius constellation, at vertical angle

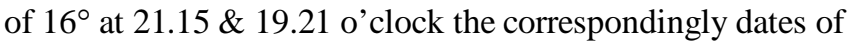
the ancient month Hekatombaion. Sagittarius constellation represents the Centaurus Hiron who, by the mythology, was taught from Apollo and Artemis botany and medicine in order to become great teacher in these fields. Among to his student was the ancient god of medicine, Asclepius. Also the path of Ophi constellation coincides successively the main axis of the theatre later in time. This constellation it is said that represents the holy snake of god Asclepius. The snake in ancient era was close related with the worship of Asclepius as during the celebration of the god (Ancient Asclepieia) many snakes were bred as they symbolize the recovery of new life. The relation of Asclepius' snake with medicine is maintained till today as an integral part of semantics.

At the theatre of Ancient Epidaurus during the same period (June $22^{\text {nd }}$ to July $21^{\text {st }}$ ), the main axis of theatre meets the Serpens constellation, at vertical angle $51^{\circ}$ at 23.10 \& 21.16 o'clock for the correspondingly dates [13]. Thus the audience is able to observe the Serpens constellation during the celebration period of Asclepieia.

At the theatre of Argos, during the celebration period of the Nemean games, June $22^{\text {nd }}$ to July $21^{\text {st }}$, the main axis of theatre meets the Aquila star at vertical angle $21^{\circ}$ at $20.00 \&$ 18.00 o'clock for the correspondingly dates [13].This star is named Altair and belongs to the constellation of Eagle. According to the myth this constellation represents the Zeus' eagle, which holds in one of its feet the Zeus' lightning and in the other Ganymede, who was brought from Troy in order to be cupbearer for Zeus and the other gods of Olympus. Also it is said that Zeus himself was transformed to an eagle in order to kidnap Ganymede from Troy and bring him to Olympus.

At the theatre of Sicyon, during the celebration date of the Apollonian games (May $1^{\text {st }}$ ) the main axis of the theatre meets the Lyra constellation at vertical angle $14^{\circ}$ at 20.52 o'clock [13]. The corresponding myth refer that Lyra's constellation represents the lyre that god Hermes gave to god Apollo as a gift. Also this was the Orpheus' lyre who was the son of Apollo and of muse Kleo. Lyre was coherent to the worship of Apollo as the flute was coherent to the worship of Dionysus.

Finally, the main axis of Delphi theatre is oriented towards the Delphinus constellation at the moment when the Lyra 
constellation is situated at the zenith of the night sky. Delphinus constellation symbolizes the dolphin which has strong relation with Apollo and the basic myth about the site of Delphi as it is consider that the place it was named after this. This phenomenon occurs four dates $21^{\text {st }}$ March-May-June and $22^{\text {nd }}$ August. However it is referred as more characteristic the March $21^{\text {st }}$, when this phenomenon takes place 18 minutes before the rising of Sun, thus it is coincided with the heliacal rising of Delphinus. That means that apart from the rising of Vega (a Lyra's), are also considered important the meridian transit of the star at the place [14].

\section{The Interaction of Topography, Audience and Orientation}

Recent researches have convinced that the facing of theatres choice was firstly based on view reasons, in particular in south of Italy, where it was found that attendants were not disturbed from sun in front, while in Sicily the preferred exposition claims for sun heating the terrace of the cavea in the first afternoon, may be a little time before attendants will be present. The second choice allows to have some late afternoon rising wind along the terrace, or cavea, so to rise up sound rays just as necessary to reduce the absorbing effect from audience' hairs. The majority of the theatres in Italy are oriented so that the audience is in front of the sea, and it is well known that in the afternoon some kind of breeze is quite always directed from the sea to earth: again we have a little rising effect for sound rays coming from the scene that, in Greek Theatres, was almost completely open on the backside [15].

Based on the above findings apart from the relation of theatres orientation with the ancient myths and constellations there are also two significant aspects that must be taken in to consideration. The first is the topography of the site where the theatre was built as the second is the convenience of the audience to watch the performances. Thus it is required that the audience doesn't be disturbed by the sun sunshine during the performance and it is also indispensable to have a nice view as they were sitting at their seats. As it is presented in figure 4 all theatres have alternative orientation far away from the East or west in order to collect the lateral sunlight and not straight either at the sunrise or the sunset, as the performances were took place during all day. Also it is notable that the theatres of Delphi and Sicyon have perpendicular orientation to each other as the theaters of Epidaurus and Dionysus have almost parallel orientation

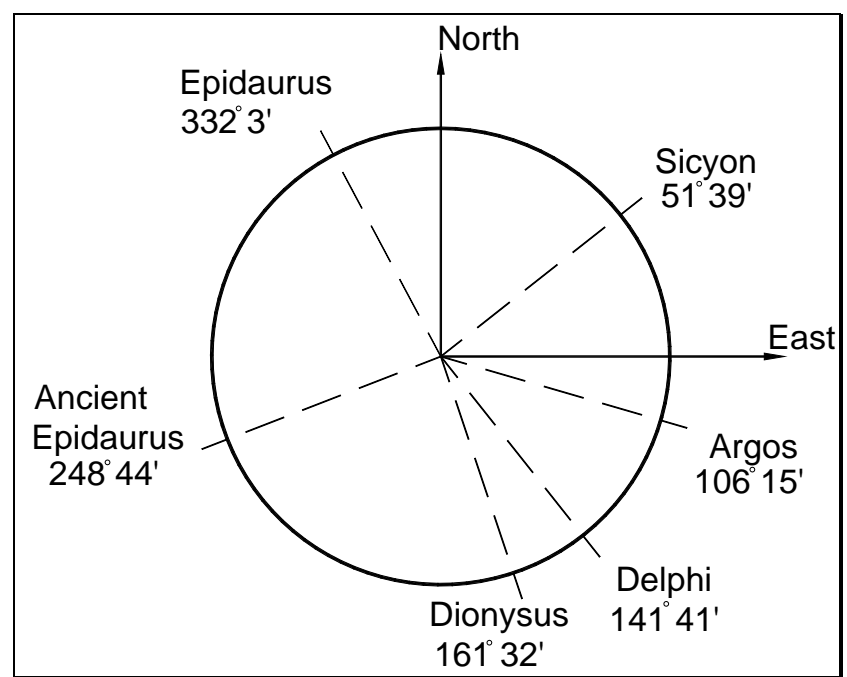

Figure 4. Representation of the astronomical orientation of the six ancient theatres

Moreover it is obvious from figures 5 and 6 that the audience of theatre of Argos and the theatre of ancient Epidaurus enjoy the wonderful view of the corresponding towns as the theatre of Sicyon (figure 7) has the view of the entire Corinth gulf. Also the ancient theatre of Delphi (figure 8) was built on a hill giving spectators a view of the entire sanctuary and the spectacular landscape below as the theatre of Epidaurus has its unique view till today figure 9. Finally Dionysus theater in Athens (figure 10) located underneath the acropolis rock with a view towards the Athens city.

In figure 11 it is also illustrated that the orientation of the four out of six theatres is towards the sea so as a breeze could be directed from the sea to earth in order to have a little rising effect for sound rays coming from the scene. As far as it concerns the theatre of Ancient Epidaurus is the one out of the six theatres that was founded almost at the sea side so have to be protected from strong winds phenomena.

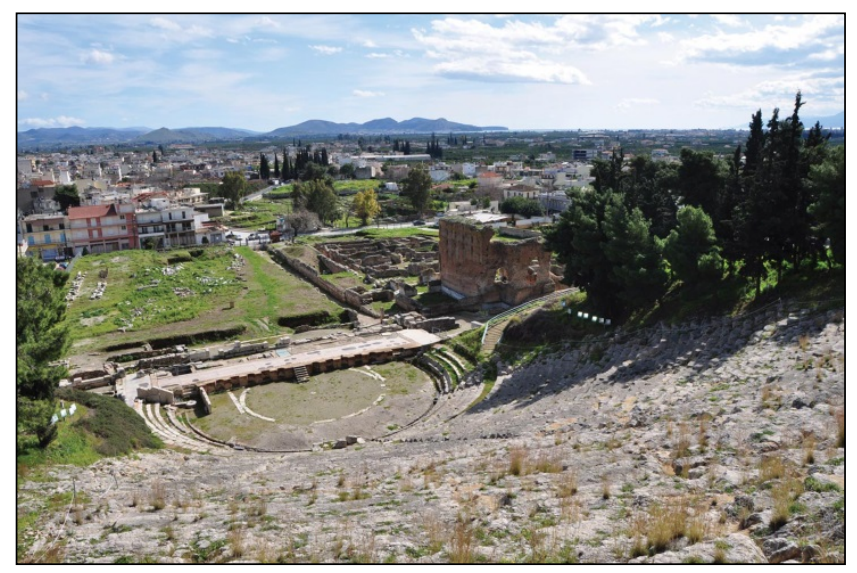

Figure 5. The view from the theatre of Argos 


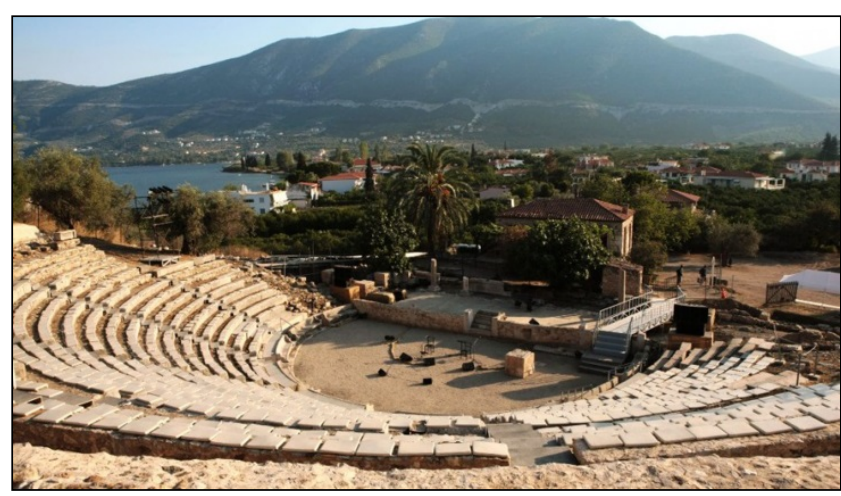

Figure 6. The view from the theatre of ancient Epidaurus

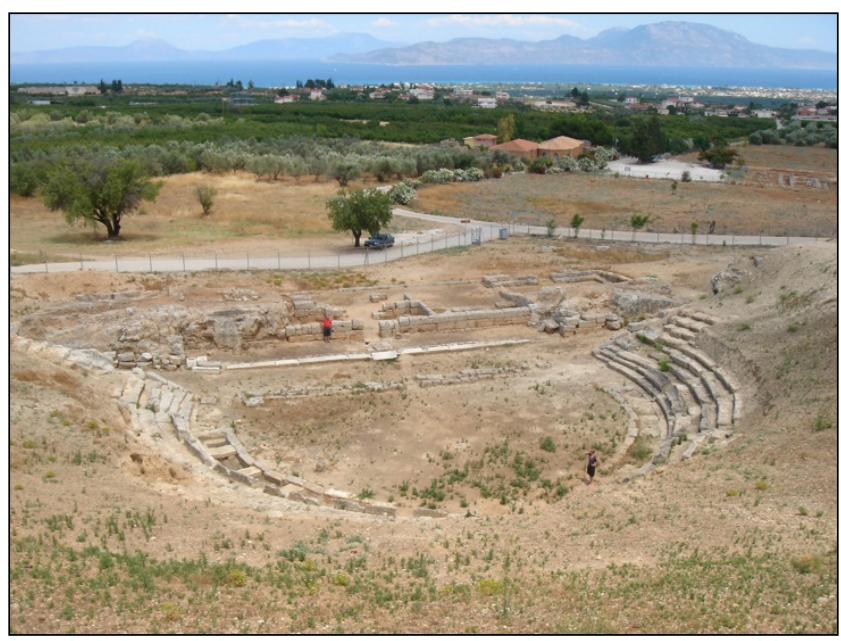

Figure 7. The view from the theatre of Sicyon

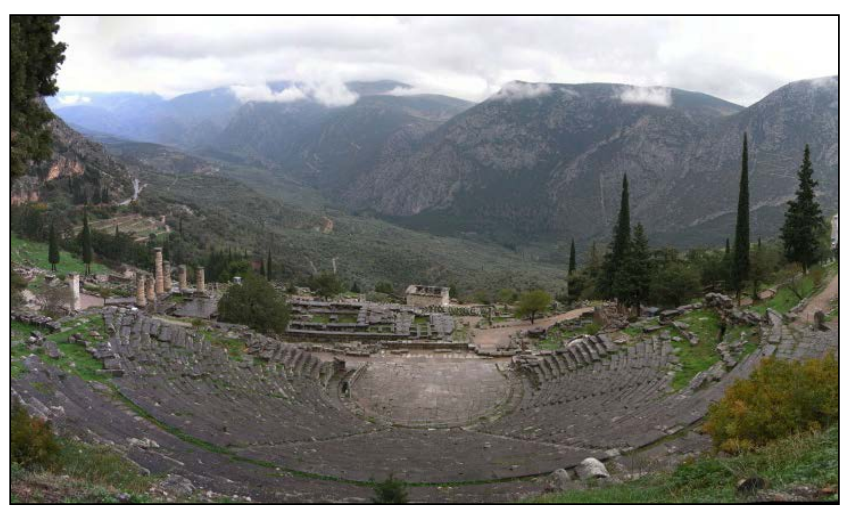

Figure 8. The view from the theatre of Delphi

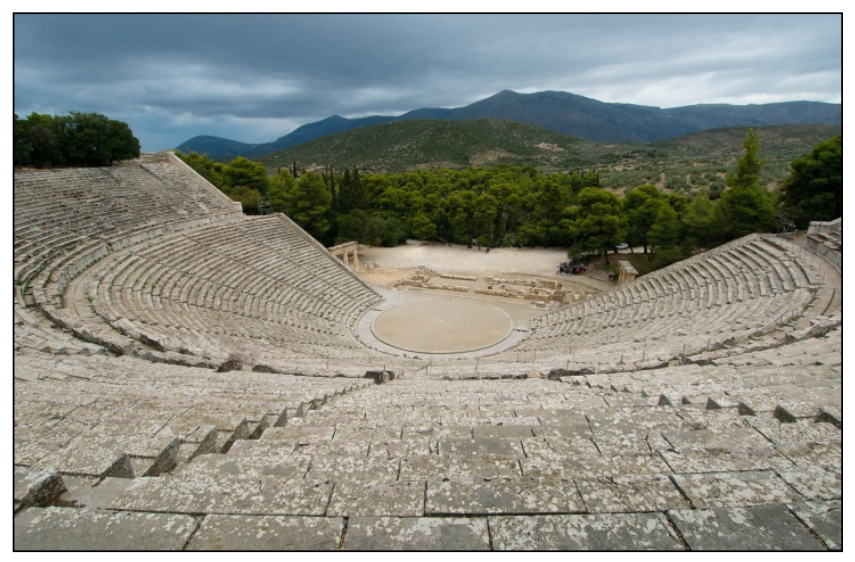

Figure 9. The view from the theatre of Epidaurus

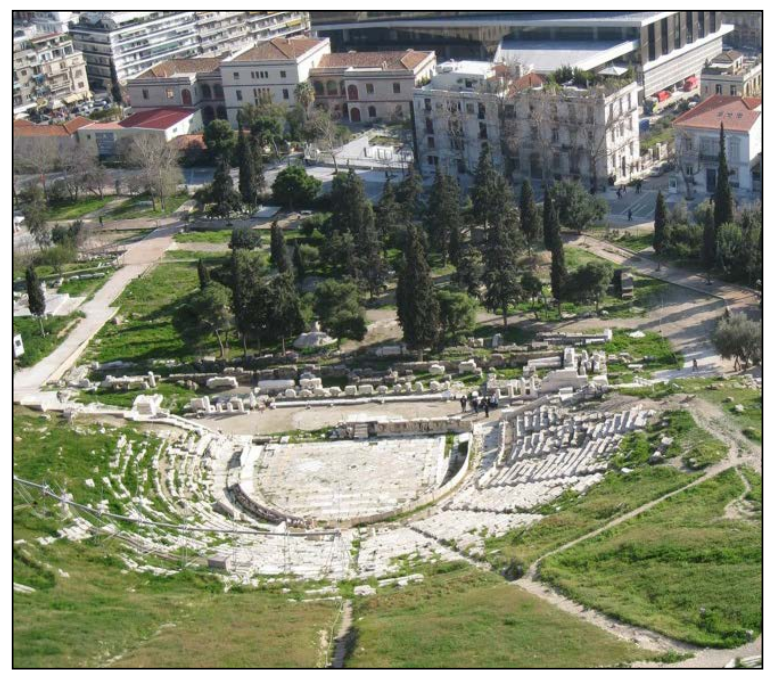

Figure 10. The view from the theater of Dionysus

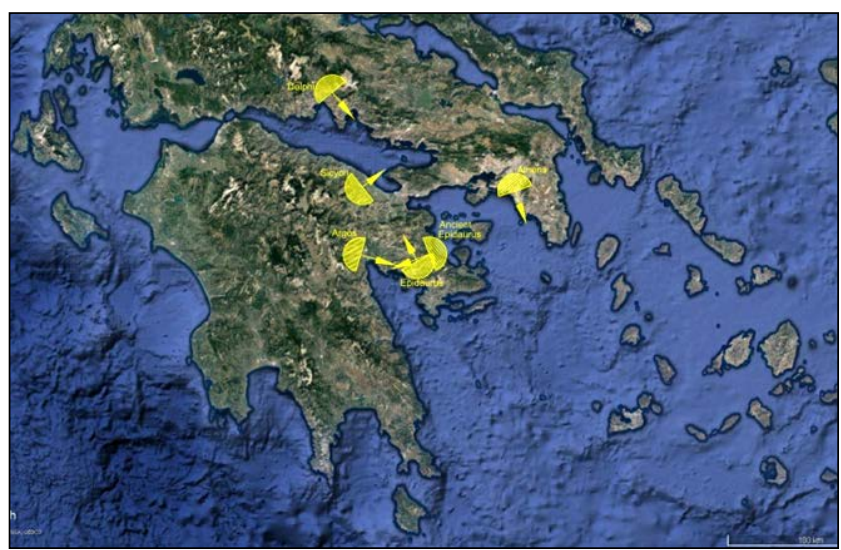

Figure 11. The site and the orientation of the six theatres, on a map 


\section{Conclusions}

The purpose of this paper is the investigation of the astronomical orientation of six ancient Greek theatres, Dionysus, Epidaurus, Ancient Epidaurus, Argos, Sicyon and Delphi. The succeeded documentation accuracy was satisfied as; the average mean square error of the final plan was up to $\pm 1 \mathrm{~cm}$. The astronomical azimuth of the main axis of each theatre, which depends on the structure status of the monument, is determined by an accuracy of \pm 1 " to $\pm 5^{\prime}$ Figures 4 and 11 summarize the astronomical orientation of theatres.

It is noted that the investigated theatres don't have a common astronomical orientation. However their orientations have a strong correlation of with specific constellations for the dates, which it is known that they were celebrated. These constellations are related to the god to whom each theatre is dedicated. The main axis of Dionysus' theatre meets the Hyades constellation, theatre of Epidaurus meets the Sagittarius and Ophiuchus constellations, Ancient Epidaurus theatre meets Serpens constellation ,the theatre of Argos meets the Aquila star which belongs to the constellation of Eagle, the theatre of Sicyon meets Lyra constellation and finally the main axis of Delphi theatre is oriented towards the Delphinus constellation at the moment when the Lyra constellation is situated at the zenith of the night sky. The above are strong evidence that their orientation is not accidentally. It is possible that their founders built them in this specific position, so as the audience to be able to observe the corresponding constellation to the celebrated god, during the performances or that this coincidence implies the end of the performance celebration day.

The convenience of the attendants plays also significant role as to not be disturbed from sunlight during the performances. For this reason none of them has exactly eastern or western orientation as the three more important of them Epidaurus, Delphi and Dionysus have such orientation so as the Sun never rise or sets on their main axis. So they receive always the Sun's light and the heat by lateral as the audience to not be disturbed. Moreover it is obvious that the orientation choice was based on view reasons and rising effect for sound rays thus the five out of six are oriented toward the sea and towards the closest village.

\section{REFERENCES}

[1] Nissen, H. (1907) Orientation. Studien zur Geschichte der
Religion. Heft 2. Weidmam, Berlin.

[2] Lockyer, N. (1964) The Dawn of Astronomy, The M.I.T. Press, Massachusetts Institute of Technology, Cambridge Massachusetts.

[3] Penrose, F. C. (1894) On the Results of an Examination of the Orientations of a Number of Greek Temples, Philosophical Transations of the Royal Society of London, vol. 184.

[4] Penrose, F. C. (1897) On the orientation of certain Greek temples and the dates of their foundation derived from astronomical considerations. Philosophical transactions of the royal society of London, Series A, vol.190, 43-65.

[5] Pantazis, G. (2002) Investigation of monuments' orientation using Geodetic and Astronomical methods: Application at Meteora, PhD Thesis (in Greek), National Technical University of Athens, School of Rural and Surveying Engineers.

[6] Pantazis, G. Lambrou, E. Korakitis, R. Sinachopoulos, D. (2004) Astrogeodetic study of the orientation of Ancient and Byzantine Monuments: Methodology and first results. Journal of Astronomical History and Heritage, vol.7 No 2, Number 14, 74-80.

[7] Pantazis, G. Papathanassiou, M. (2005) On the date of the Katholikon of Daphni monastery. A new approach based on its orientation. Mediterranean Archaeology and Archaeometry, vol. $5,63-72$.

[8] Pantazis, G. Lambrou, E. (2009) Investigating the orientation of eleven mosques in Greece. Journal of Astronomical History and Heritage, vol.12, 159-166.

[9] Pantazis, G. (2014) The symmetric placing and the dating of Parthenon and Hephaisteion in Athens (Greece). Mediterranean Archaeology and Archaeometry, Vol. 14, No 2, pp. 273-279.

[10] Ashby, C. (1999) Classical Greek Theatre: New Views of an Old Subject, University of lowa Press, ISBN 0-87745-641-0

[11] http://whc.unesco.org/en/tentativelists/5869/ (last access 9/2017)

[12] http://whc.unesco.org/en/list/491 (last access 9/2017)

[13] Dimitrakakis, I. (2014) Investigation of the astronomical orientation of the ancient theatres of Dionysus, Epidaurus, Ancient Epidaurus, Argos and Sicyon Unpublished diploma dissertation (in Greek), NTUA, School of Rural and Surveying Engineering, Athens.

[14] Gouma, P. (2014) Investigation of the orientation of the ancient theatres of Delphi Unpublished diploma dissertation (in Greek), NTUA, School of Rural and Surveying Engineering, Athens.

[15] Cocchi, A. (2011) Theatre design in ancient times: Science or opportunity?, The Acoustics of Ancient Theatres Conference, Patras, Greece. 